\title{
APPROACH TO THROMBOCYTOPENIA- A CLINICOPATHOLOGICAL STUDY
}

\author{
Gireesh Vishnupant Achalkar' ${ }^{1}$ Kusuma ${ }^{2}$
}

${ }^{1}$ Associate Professor, Department of Pathology, Raichur Institute of Medical Sciences, Raichur.

2Postgraduate Student, Department of Community Medicine, Navodaya Medical College, Raichur.

\section{ABSTRACT}

\section{BACKGROUND}

Thrombocytopenia is defined as decreased number of platelets below 1.0 lakh/ $\mu \mathrm{L}^{1}$ and it may be due to one of four causes: Decreased production, increased destruction, bone marrow failure or splenic sequestration. ${ }^{2}$

Objective- To find out the cause of thrombocytopenia in febrile patients with age, sex distribution and extent of thrombocytopenia.

\section{MATERIALS AND METHODS}

The study was conducted with 500 cases of thrombocytopenia with fever. All the patients with platelet count less than 1.0 lakh/ $\mu \mathrm{L}$ were included and clinic pathological correlation was done.

Statistical analysis: Simple random sampling, mean and percentage.

\section{RESULTS}

The most common cause for thrombocytopenia was dengue viral infection, ${ }^{3}$ followed by other viral infections, malaria and noninfective causes. Maximum number of patients were in the age group of 10-25 years.

\section{CONCLUSION}

Thrombocytopenia is an important pathological indicator of infection like dengue, malaria and sepsis. It is also common in noninfective conditions like alcoholism and malignancies.

\section{KEYWORDS}

Thrombocytopenia, Dengue, Sepsis, Malaria.

HOW TO CITE THIS ARTICLE: Achalkar GV, Kusuma. Approach to thrombocytopenia- A clinicopathological study. J. Evolution Med. Dent. Sci. 2017;6(37):3003-3006, DOI: 10.14260/Jemds/2017/648

\section{BACKGROUND}

Purpura in association with pestilential fevers was described by Hippocrates and later writers, but it was not until the $16^{\text {th }}$ century and the early part of $17^{\text {th }}$ century that purpura in the absence of fever was recognised.

In 1735, Werlhof distinguished morbus maculosus haemorrhagicus as a separate entity, and in 1808 Willan classified purpura under the headings simplex, haemorrhagica, urticaris and contagiosa thus separating the types later described by Schonlein (1829) and Henoch (1868) that now bear their names.

The marked diminution in haematoblasts (platelets) in purpura haemorrhagica was recognised by Krauss (1883) and Denys (1887). Hayem (1895) noted the nonretractility of the blood clot, and Duke (1912) demonstrated the prolonged bleeding time. Abnormal capillary fragility was observed by writers in different countries. ${ }^{2}$

Platelets are formed by cytoplasmic fragmentation of megakaryocytes in the bone marrow. They are mainly involved in clotting mechanism and also they act as acute phase reactants.

Financial or Other, Competing Interest: None.

Submission 15-03-2017, Peer Review 25-04-2017,

Acceptance 01-05-2017, Published 08-05-2017.

Corresponding Author:

Dr. Gireesh Vishnupant Achalkar,

Associate Professor,

Department of Pathology,

Raichur Institute of Medical Sciences,

Raichur-584102, Karnataka.

E-mail: drgireesha@yahoo.com

DOI: $10.14260 /$ jemds $/ 2017 / 648$

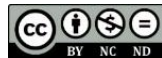

They have an average life span of 7 days. Thrombocytopenia is defined as the platelet count below 1.0 lakh/ $\mu \mathrm{L}$. The normal range being 1.5 to $4.5 \mathrm{lakh} / \mu \mathrm{L} .1 .0$ to 1.5 lakh is the grey zone and does not usually cause any haemostatic problems.

The relevance of thrombocytopenia in the individual patient is variable and depends on the clinical presentation. Because platelets play an essential role in preserving vessel wall integrity, thrombocytopenia is associated with a defect of primary homoeostasis.

\section{MATERIALS AND METHODS}

The study was conducted for a period of three months from October 2016 to December 2016, which included the cases with platelet count less than $1.0 \mathrm{lakh} / \mu \mathrm{L}$ found in complete blood count $(\mathrm{CBC})$ and correlated with peripheral smear study.

Cases not febrile and cases with platelet counts more than 1.0 lakh/ $\mu \mathrm{L}$ were excluded from study. The CBC was done on Sysmex KX21 automated haematology analyser. Clinical history of the patients was traced and correlated with platelet counts and other laboratory findings.

\section{Thrombocytopenia was graded as follows}

- $\quad 50,000$ - 1.00 lakh/ $\mu \mathrm{L}-$ Grade I

- $20,000-50,000 / \mu \mathrm{L}$ - Grade II

- $10,000-20,000 / \mu \mathrm{L}-$ Grade III

- $\quad<10,000 / \mu \mathrm{L}-$ Grade IV 


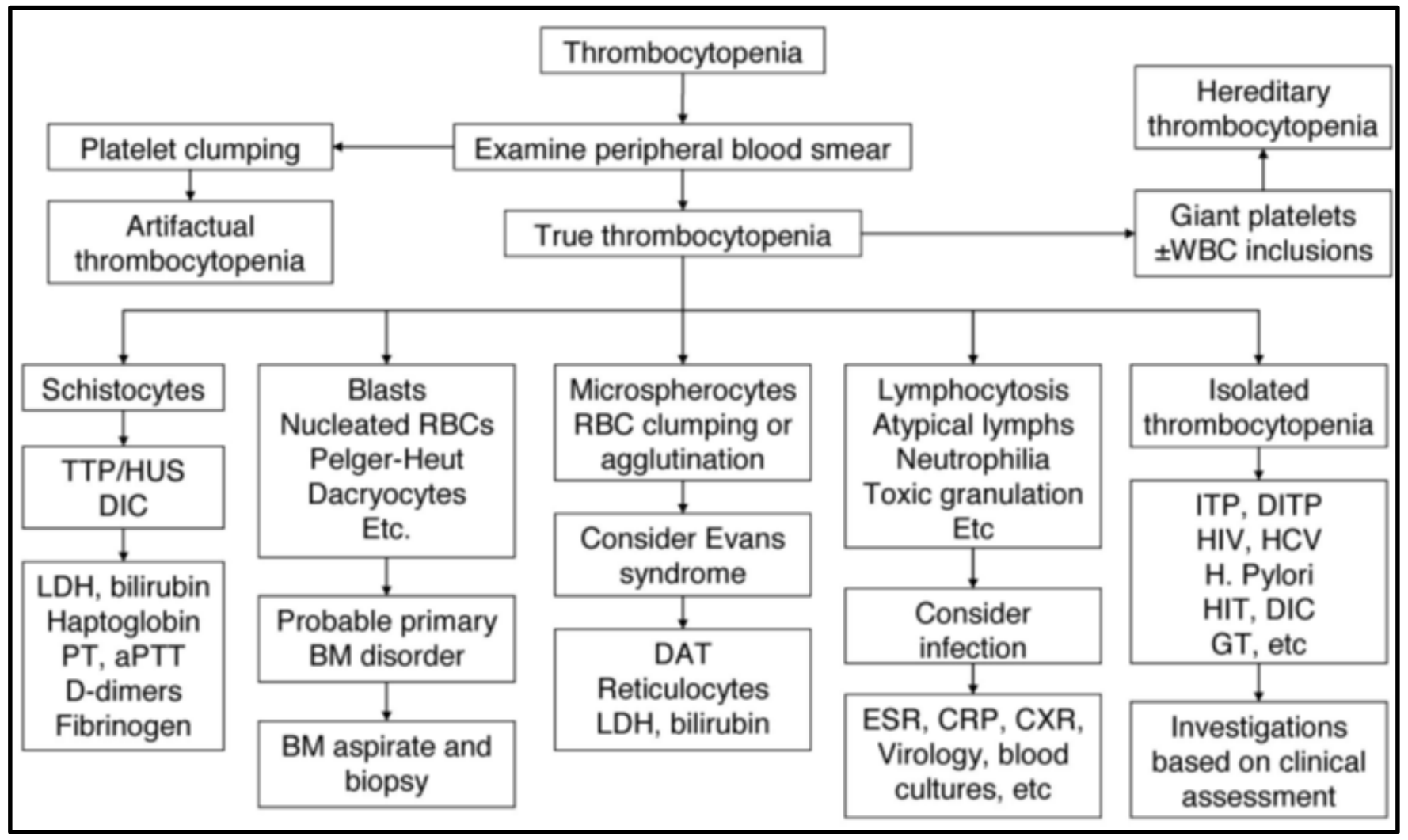

Figure 1. Algorithm for Workup of Thrombocytopenia Based on Observation of the Peripheral Blood Film

TTP/HUS indicates thrombotic thrombocytopenic purpura/haemolytic uremic syndrome.

\section{RESULTS}

A total of 500 patients were selected between October 2016 to December 2016 by simple random sampling and were categorised according to age, sex, clinical history and other positive laboratory findings. ${ }^{4,5}$

Out of which maximum number of patients were in the age group of 00-20 Years (250 cases, in Percentage 50\%) followed by 21-40 Years and least in the age group of 41-60 Years.

Infectious aetiology was the most common cause with dengue viral infection being the principle aetiology followed by sepsis and malaria.

Grade I Thrombocytopenia was most common and Grade IV was least common.

\begin{tabular}{|c|c|c|}
\hline Age group & No. of Cases & \% Percentage \\
\hline 0 - 20 years & 250 & $50.0 \%$ \\
\hline $21-40$ years & 140 & $28 \%$ \\
\hline $41-60$ years & 41 & $8.2 \%$ \\
\hline $61-80$ years & 57 & $11.4 \%$ \\
\hline$>80$ years & 12 & $2.4 \%$ \\
\hline Total & $\mathbf{5 0 0}$ & $\mathbf{1 0 0 \%}$ \\
\hline \multicolumn{3}{|c|}{ Table 1. Age Distribution } \\
\hline
\end{tabular}

Majority of the cases were in the age group of 0-20 Years, followed by 21-40 Years.

\begin{tabular}{|c|c|c|}
\hline Sex & No. of Cases & \% Percentage \\
\hline Male & 338 & $67.6 \%$ \\
\hline Female & 162 & $32.4 \%$ \\
\hline Total & $\mathbf{5 0 0}$ & $\mathbf{1 0 0 \%}$ \\
\hline \multicolumn{2}{|c|}{ Table 2. Sex Distribution } \\
\hline
\end{tabular}

Males were affected in more number of cases than female patients.

\begin{tabular}{|c|c|c|}
\hline Causes & No. of Cases & \% Percentage \\
\hline Dengue & 138 & $27.6 \%$ \\
\hline Sepsis & 102 & $20.4 \%$ \\
\hline Malaria & 95 & $19.0 \%$ \\
\hline Hepatitis & 70 & $14.0 \%$ \\
\hline Chikungunya & 13 & $2.6 \%$ \\
\hline Typhoid & 48 & $9.6 \%$ \\
\hline Fungal infections & 08 & $1.6 \%$ \\
\hline Others & 18 & $3.6 \%$ \\
\hline Total & 500 & $100 \%$ \\
\hline
\end{tabular}

The most common infectious cause for thrombocytopenia was dengue viral infection.

\begin{tabular}{|c|c|}
\hline MPV Ranges & Number of Patients \\
\hline Low $(<6.9 \mathrm{fl})$ & 78 \\
\hline High $(>10.6 \mathrm{fl})$ & 282 \\
\hline Normal $(6.9-10.6 \mathrm{fl})$ & 140 \\
\hline Total & 500 \\
\hline \multicolumn{2}{|c|}{ Table 4. Mean Platelet Volume (MPV) } \\
\hline
\end{tabular}

\begin{tabular}{|c|c|}
\hline PDW & Number of Patients \\
\hline Low $(<11 \mathrm{fl})$ & 44 \\
\hline High $(>16 \mathrm{fl})$ & 311 \\
\hline Normal $(11-16 \mathrm{fl})$ & 145 \\
\hline Total & 500 \\
\hline Table 5. Platelet Distribution Width (PDW) \\
\hline
\end{tabular}




\section{Other Laboratory Findings}

Dengue viral infection was frequently associated with haemoconcentration, raised AST and ALT enzymes and leukopenia. Whenever thrombocytopenia is associated with these findings, it was dengue in majority cases. The severity of thrombocytopenia was more in secondary than in primary dengue viral infection.

In malaria also, mild-to-moderate degree of elevation of AST and ALT was seen in some of the cases depending on the stage of life cycle of plasmodium. Haemoglobinuria was seen in some patients indicating intravascular haemolysis, and there was unconjugated hyperbilirubinaemia.
Sepsis was characterised by leucocytosis or leukopenia with shift to left, and various degree of organ failure including raised creatinine, bilirubin and hypo or hyperkalaemia. Other diseases had characteristic associated findings including early organ failure.

\section{DISCUSSION}

There are various causes for thrombocytopenia seen in outpatients, inpatients and pregnant women. They can be classified as follows.

\begin{tabular}{|c|c|c|c|}
\hline \multirow[b]{2}{*}{ Outpatient } & \multicolumn{2}{|c|}{ Inpatient } & \multirow[b]{2}{*}{ Pregnancy/Postpartum } \\
\hline & $\begin{array}{c}\text { Multisystem } \\
\text { Illness/ICU }\end{array}$ & Cardiac Patient & \\
\hline $\begin{array}{c}\text { ITP } \\
\text { DITP } \\
\text { Infections } \\
\text { HIV } \\
\text { Hepatitis C virus } \\
\text { Helicobacter pylori } \\
\text { CMV } \\
\text { Other recent viral infections } \\
\text { Connective tissue disorders } \\
\text { Systemic lupus erythematosus } \\
\text { Rheumatoid arthritis } \\
\text { Antiphospholipid syndrome } \\
\text { Vaccinations } \\
\text { Myelodysplastic syndromes } \\
\text { Congenital thrombocytopenia } \\
\text { Common variable immunodeficiency }\end{array}$ & $\begin{array}{c}\text { Infections } \\
\text { TTP/HUS } \\
\text { DITP } \\
\text { DIC } \\
\text { Liver disease } \\
\text { HIT } \\
\text { MAS } \\
\text { BM disorders } \\
\text { CIT }\end{array}$ & $\begin{array}{c}\text { HIT } \\
\text { Cardiac bypass } \\
\text { GPIIb/IIIa inhibitors } \\
\text { Other DITP } \\
\text { Dilutional }\end{array}$ & $\begin{array}{c}\text { GT } \\
\text { ITP } \\
\text { HELLP syndrome } \\
\text { Preeclampsia } \\
\text { Abruptio placentae } \\
\text { TTP/HUS }\end{array}$ \\
\hline
\end{tabular}

TTP/HUS indicates thrombotic thrombocytopenic purpura/haemolytic uremic syndrome; MAS, macrophage activation syndrome (Including haemophagocytic syndrome); CIT, chemotherapy-induced thrombocytopenia; HELLP, haemolysis, elevated liver enzymes, and low platelets.

Bleeding time increase if the platelet count is below $50,000 / \mu \mathrm{L}$ and the risk of spontaneous intracranial haemorrhage increases rapidly if the platelet count falls below $5000 / \mu \mathrm{L}$.

Age correlation was done with most cases falling in the age group of $0-20$ years followed by 21 to 40 years age group, the least being in the age group of over 80 years probably because the number of patients $>80$ years is very less.

Of the 500 cases, males were affected in more number of cases compared to females. These findings were similar to the study conducted by Lakdum et al. ${ }^{6}$ A total of 500 patients were studied of which $65.2 \%$ were male and $34.8 \%$ were female.

Prospectively the 500 cases were studied and it was found that infection was the most common cause and among them dengue was the commonest. The study was correlated with Bhalara et $\mathrm{al}^{7}$ in which dengue was principle aetiology for thrombocytopenia. But it differs with that of Lakdum et $\mathrm{el}^{6}$ in which malaria was the most common cause. The cause of this variation was may be due to regional and seasonal differences.

Thrombocytopenia is a common feature of dengue viral infection primary or secondary. The severity of thrombocytopenia was more in secondary dengue infection compared to primary one, peripheral platelet destruction was the principle cause. Thrombocytopenia was the hallmark haematological feature of malaria ${ }^{8}$ seen in both vivax and falciparum infections.

The correlation between thrombocytopenia and malaria was more than $95 \%$. Only one case which was positive for plasmodium vivax had platelet count 1.53 lakhs/ $\mu \mathrm{L}$ and even that case after 2 days of followup with repeat $\mathrm{CBC}$ showed platelet count falling to $98000 / \mu \mathrm{L}$ establishing the fact that the correlation is almost near to $100 \%$.

It is postulated that it is most probably due to binding of malarial antigens to the surface of platelets that causes antimalarial antibodies forming in situ immune complexes and then destruction of platelets. ${ }^{9}$ The fall of platelet count is independent of age, duration of illness, spleen size or parasite Index. ${ }^{10,11}$

Sepsis due to various causes like UTI, acute cholecystitis, bronchopneumonia was the important clinical scenario for thrombocytopenia especially for patients admitted to ICU for various reasons $\mathbf{s}^{12,13}$.

Among liver diseases, non- $A$, non- $B$, non-C hepatitis was the most common cause followed by Hepatitis B, Hepatitis C and Alcoholic liver disease. Most of the patients with portal hypertension had Grade I - II thrombocytopenia. Other causes included HIV infection, typhoid fever, DIC, etc.

Thrombocytopenia is the most common clinicopathological finding in various diseases especially common in our country. Infections are particularly common during monsoon and there can be consequence of decreased platelet count resulting in bleeding disorder. ${ }^{14}$ 
These is an urgent need to be aware of various aetiological factors leading to thrombocytopenia so that patients are better managed and steps taken to control mosquito borne infections.

Our results demonstrate that platelet indices are significantly higher in infective thrombocytopenia. Therefore, these indices are effective in distinguishing infective and immune thrombocytopenia from other types and these findings are consistent with previous findings of Borkataky et $\mathrm{al}^{15}$ where platelet indices ${ }^{16}$ were found to be useful in the differential diagnosis of infective and immune thrombocytopenia from other causes.

\section{Heparin-induced thrombocytopenia}

Approximately, $10-20 \%$ of patients will develop a transient mild thrombocytopenia after 1 to 4 days of heparin therapy. The platelet count rarely goes below one lakh /microlitre, often becomes normal despite further heparin administration and is generally without clinical sequelae.

This benign form of heparin-induced thrombocytopenia is attributed to direct interaction between administered heparin at circulating platelets. ${ }^{17,18}$

\section{CONCLUSION}

Dengue viral infection is the most common cause for thrombocytopenia followed by malaria and other causes. A low platelet count can result from a wide range of conditions and may be determined by multiple mechanisms.

Prompt recognition of the cause of thrombocytopenia is often crucial for the correct management of patients as in acute leukaemia, heparin-induced thrombocytopenia, dengue, malaria or sepsis. The initial approach in determining the cause of thrombocytopenia is based on the patient's history and careful examination of peripheral blood smear.

The most common cause of low platelet count in patients with fever is infection due to virus, parasite or bacteria.

\section{REFERENCES}

[1] Kumar, Abbas, Aster, et al. Robbins and Cotran pathologic basis of disease. $8^{\text {th }}$ edn. Elsevier Health Sciences Division 2010; p. 687.

[2] Rodgers GM. Thrombocytopenia: pathological classification. In: Greer JP, Foerster J, Rodgers GM, et al. eds. Wintrobes Hematology. 12 $2^{\text {th }}$ edn. Philadelphia PA: Lippincott Williams and Wilkins 2013; p. 2451.

[3] Yeolekar ME, Munjal YP, Sharma SK, et al. API textbook of medicine. 9th edn. Jaypee Brothers Publishers 2013; p. 1158.
[4] Sekhon SS, Roy V. Thrombocytopenia in adults: a practical approach to evaluation and management. South Med J 2006;99(5):491-8. quiz 499-500,533.

[5] Gandhi AA, Akholkar PJ. Clinical and laboratory evaluation of patients with febrile thrombocytopenia Natl J Med 2015;5(1):43-6.

[6] Lakum N, Makwane H, Shah R. A study of laboratory profile of fever with thrombocytopenia in adult patients at C.U. Shah Medical college, Surendranagar. SEAJCRR 2014;3(1):556-61.

[7] Bhalara SK, Shah S, Goswami H, et al. Clinical and etiological profile of thrombocytopenia in adults: a tertiary-care hospital-based cross-sectional study. Int J Med Sci \& Public Health 2015;4(1):7-10.

[8] Skudowitz RB, Katz J, Lurie A, et al. Mechanism of Thrombocytopenia in malignant tertian malaria. $\mathrm{Br}$ Med J 1973;2(5865):515-8.

[9] Kelton JG, Keystone J, Moore J, et al. Immune-mediated thrombocytopenia in malaria. J Clin Invest 1983;71(4):832-6.

[10] Srikanth J, Srinivas S, Krishna CRPS, et al. Prevalence of thrombocytopenia in a diagnosed cases of malaria in rural population in south India. J NTR Univ Health Sci 2012;1(3):152-5.

[11] Horstmann RD, Dietrich, Bienzle U, et al. Malaria induced thrombocytopenia. Blut 1981;42(3):157-64.

[12] Waters AH. Autoimmune thrombocytopenia; clinical aspects. Semin Hematol 1992:29(1):18-25.

[13] Schwartz SI, Hoepp LM, Sachs S. Splenectomy for thrombocytopenia. Surgery 1980;88(4):497-506.

[14] Sopo SM, Pesaresia MA, Celestini E, et al. Pathogenesis of thrombocytopenia in TAR syndrome. Am J Pediatr Hematol Oncol 1992;14(2):186-7.

[15] Borkataky S, Jain R, Gupta R, et al. Role of platelet indices in the differential diagnosis of thrombocytopenia: a simple and inexpensive method. Hematology 2009;14(3):182-6.

[16] Kaito K, Otsubo H, Usui N, et al. Platelet size deviation width, platelet large cell ratio and mean platelet volume have sufficient sensitivity and specificity in the diagnosis of immune thrombocytopenia. $\mathrm{Br} \mathrm{J}$ Haemotol 2005;128(5):698-702.

[17] Chong BH. Heparin-induced thrombocytopenia. Aust N Z J Med 1992;22(2):145-52.

[18] Warkentin TE, Kelton JG. Heparin and platelets. Haemotol Oncol Clin North Am 1990;4(1):243-64. 